\title{
Acetylcholinesterase from Curimatã Fish Brain (Prochilodus Brevis) as Potential Biocatalyst for Voltammetric Biosensor Construction
}

\author{
Giovanni Ortiz Leoncini, Emanuella Gomes da Silva, Sônia Salgueiro Machado and Fabiane Caxico de Abreu* \\ Institute of Chesmitry and Biotechnology, Federal University of Alagoas Maceió, Brazil
}

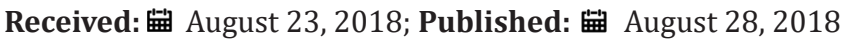

*Corresponding author: Fabiane Caxico de Abreu, Institute of Chesmitry and Biotechnology, Federal University of Alagoas Maceió, AL, 57072-900, Brazil

\begin{abstract}
Background: The AChE (acetylcholinesterase) is a serine hydrolase responsible for terminating neurotransmission by hydrolyzing the acetylcholine released on synaptic cleft. Studies of AChE as a target of pesticide toxicity have yielded several practical outcomes and are the basis for constructing biosensors. These devices are primarily designed to determine and quantify the inhibition of AChE by toxic chemicals.

Objective: to construct a biosensor based on acetylcholinesterase from the brain of the Prochilodus brevis fish, and to use the same as biomarker of agrochemicals that inhibit the enzyme.

Methods: Acetylcholinesterase was isolated from curimatã fish brain (prochilodus brevis) and partially purified using amonium sulfate precipitation followed by size-exclusion chromatography (ChE1). AChE from curimatã fish brain was directly immobilizes on the surface of glassy carbon electrode modified with multi-walled carbon nanotubes.

Results: Acetylcholinesterase was characterized as having a specific activity of $0.194 \mathrm{U} / \mathrm{mg}$. The optimum activity was found at pH 8.5 , phosphate buffer $0.7 \mu \mathrm{M}, 28^{\circ} \mathrm{C}$ and exhibited a thermostability at $37^{\circ} \mathrm{C}$. The glassy carbon modified electrode exhibits excellent electrocatalytic activity to the increase of thiocholine, with a linear response in the $0.05 \mathrm{mM}$ to $0.85 \mathrm{mM}$ concentration range, with a $73 \mu \mathrm{M}$ limit of detection and with a $240 \mu \mathrm{M}$ limit of quantification.

Conclusion: The AChE from curimatã fish brain allowed the modification of the glassy carbon electrode providing a potential sensor detection system that can be used for determination of thiocholine (pesticides) in real samples of environmental importance.
\end{abstract}

\section{Introduction}

Acetylcholinesterase (AChE) is present in all vertebrates, particularly in the muscles and nervous tissues [1]. AChE is a serine hydrolase (EC. 3.1.1.7) localized between the nerve terminal and post-synaptic membrane responsible for terminating neurotransmission by hydrolyzing the acetylcholine released on synaptic cleft, is being one of the most efficient enzyme reactions $[1,2]$. Studies of AChE as a target of pesticide toxicity have yielded several practical outcomes and are the basis for constructing biosensors. These devices are primarily designed to determine and quantify the inhibition of AChE by toxic chemicals. Depending on the extraction source, these enzymes can have different substrate specificity and susceptibility to inhibitors [3]. The several different molecular forms which are dependent of enzyme gene shown variable catalytic properties of AChE $[4,5]$. Apart these, the physiological meaning of different forms and molecular interactions allow various types of AChE in different tissues and physiological conditions [4]. These various AChE forms have been a motivation for build a voltammetry biosensor applied for a specific ecosystem.
Fish are a group of great importance in environmental toxicity evaluations, as well as being present in various environments and present wide geographical distribution, still participate in different trophic levels of the food chain, being regarded as excellent biological models to study. Prochilodus brevis is a native fish of the San Francisco river, one of the largest watercourses of Brazil, has a huge regional importance of viewpoints ecological, economic and social. Besides, the effluents generated by the disorderly occupation are contamination promoted using agrochemicals of the agricultural activity in the surroundings of the river, which generates a concern about the contamination of the aquatic systems. The present work proposes to construct a biosensor based on acetylcholinesterase from the brain of the Prochilodus Brevis fish, native to the region, and to use the same as biomarker of agrochemicals that inhibit the enzyme, providing greater specificity. The electrochemical system builded will provide a biosensor for sensing thiocholine from AChE isolated of a real biological model. 


\section{Materials and Methods \\ Partial Purification of Prochilodus Brevis AChE}

Prochilodus brevis brains were captured and collected in fish farming of San Francisco hydroelectric company (CHESF) in the Bahia state, Brazil. The brains were extracted and stored in tubes immediately immersed in liquid nitrogen and then frozen in the freezer until preparation of the crude extract. Brains were macerated with suspension buffer $(20 \mathrm{mM}$ Tris- $\mathrm{HCl}, \mathrm{pH} 7.5$ in $0.1 \%$ Triton) followed by homogenization in glass homogenizer. The crude extract was subjected to 5 cycles on ultrasonic device for 15 seconds each cycle at 15 second intervals in an ice bath. For 20 minutes at $4^{\circ} \mathrm{C}$ the material was centrifuged at $10,000 \mathrm{rpm}$. The supernatant (cell free extract) was collected and stored at $4^{\circ} \mathrm{C}$ until the salt precipitation step. The salting out (salt precipitation) method was applied with ammonium sulphate on the cell free extract. The highest AChE activity was found on $40 \%(\mathrm{w} / \mathrm{v}$ ) fraction after $3 \mathrm{~h}$ shaking. The fraction was dialyzed three times and keeping overnight to remove salt excess. The enzymatic sample was applied directly to a Sephacryl S-100 $(60 \mathrm{~cm} \times 1 \mathrm{~cm})$ equilibrated with Tris$\mathrm{HCl} 20 \mathrm{mM}$ in Triton $\mathrm{x} 100(0,1 \%), \mathrm{NaCl} 0,25 \mathrm{M}, \mathrm{pH}$ 8.0. Elution of the fractions containing AChE was eluted with the same buffer. The fraction having was concentrated by poly (ethylene glycol) (PEG) on membrane filter. Finally, the concentrate fraction containing highest AChE activity (ChE1) were stored at $4^{\circ} \mathrm{C}$ awaiting the electrochemical measurements [6].

\section{Enzyme Assay}

AChE activity was measured by colorimetric method of [7]: 93 $\mathrm{mM}$ of potassium phosphate buffer, $\mathrm{pH} 8,0 ; 100 \mu \mathrm{L}$ enzyme sample; $3.3 \mathrm{mM}$ of 5,5'-dithiobis (2-nitrobenzoic acid), DTNB; $0.5 \mathrm{mM}$ of the substrate acetylthiocholine iodide (ATCh) and the absorbance change was monitored in $412 \mathrm{~nm}$ at $25^{\circ} \mathrm{C}$. One unit of activity (U) was defined as $\mu \mathrm{mol}$ of hydrolyzed substrate per minute. The specific activity was expressed as units of activity per mg of protein. Protein contents were determined by Bradford assay.

\section{pH, Ionic Strength, Temperature and Thermostability}

The enzyme parameters were studied with gradients of buffer concentration from 0.01 to $0.35 \mathrm{M}$ and $\mathrm{pH}$ from 4.5 to 9.0 was done for determine optimum ionic strength and $\mathrm{pH}$. The temperature variation $\left(20-46^{\circ} \mathrm{C}\right)$ of buffer and enzyme sample incubated for $10 \mathrm{~min}$ for each temperature show optimum temperature and then, the heated enzymatic solution was kept at $25^{\circ} \mathrm{C}$ for $10 \mathrm{~min}$ to restore the activity lost due to reversible inactivation for thermostability evaluation.

\section{Electrochemical Experiments}

Cyclic and differential pulse voltammetry experiments (CV and DPV) were carried out with an Autolab PGSTAT128N controlled by NOVA 1.1 software. The electrochemical system consisted of glassy carbon electrode (GCE - working electrode), silver wire (auxiliary electrode) and $\mathrm{Ag}|\mathrm{AgCl}| \mathrm{Cl}$ - (reference electrode). The GCE was modified by physical adsorption of $10 \mu \mathrm{L}$ of MWCNT (multiwalled carbon nanotube), $5 \mathrm{~min}$ at $70^{\circ} \mathrm{C}$, $1 \mathrm{~L}$ per addiction. The enzyme sample was added $10 \mu \mathrm{L}$ on the modified electrode.
After $1 \mathrm{~h}$ of incubation at $4^{\circ} \mathrm{C}$, the electrode was gently introduced on buffer potassium phosphate of electrochemical cell system. All the experiments were carried out at room temperature. Before each voltammetry experiment, the work solution was degasified with pure nitrogen and magnetically stirred for $5 \mathrm{~min}$. The scanning of oxidation potential in DPV was set a range of $0,0-1,0 \mathrm{mV}$ for signal detection of thiocholine oxidation around $650 \mathrm{mV}$.

\section{Results and Discussion}

\section{Partial Purification of Prochilodus Brevis AChE}

The AChE cell free extract had specific activity of $0.310 \mathrm{U} /$ mg and then, salting out method increased the specific activity to $0.395 \mathrm{U} / \mathrm{mg}$. The further purification was carried out using size exclusion chromatography on a Sephacryl S-100 (Figure 1A), column equilibrated with Tris- $\mathrm{HCl} 20 \mathrm{mM}$ in Triton x100 $(0,1 \%)$, $\mathrm{NaCl}$ 0.25M, pH 8.0. AChE was eluted using the same buffer and the chromatographic step decreased the specific activity to $0.194 \mathrm{U} /$ $\operatorname{mg}[8,9]$.

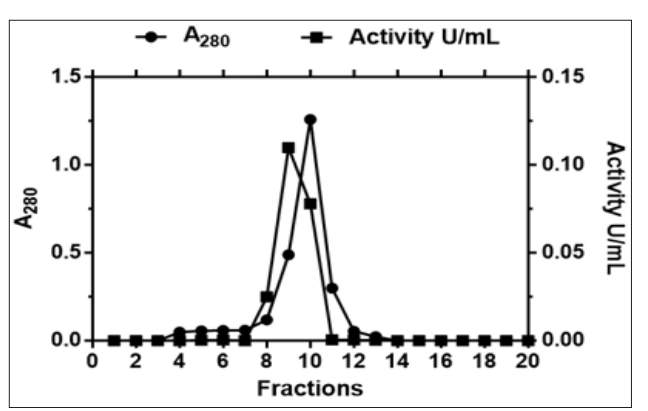

Figure 1: Size-exclusion chromatography of AChE on a Sephacryl S-100 column.

\section{Stability of AChE from Prochilodus brevis}

The $\mathrm{pH}$ gradient affect enzyme stability by ionizations states of the side chains. The stability of AChE was tested by different $\mathrm{pH}$ at room temperature. The optimum $\mathrm{pH}$ (Figure 2A) was 8.5 with stability range at 8.0 to 9.5. The optimum ionic strength (Figure $2 \mathrm{~B}$ ) show highest activity at $0,08 \mathrm{M}$, but above $1.0 \mathrm{M}$ show desestability with decrease activity. The optimum temperature (Figure $3 \mathrm{~A}$ ) of $28^{\circ} \mathrm{C}$, immediately afterwards the sudden drop of activity from $31^{\circ} \mathrm{C}$ to $46^{\circ} \mathrm{C}$ is observed. Normally, the AChE show $35^{\circ} \mathrm{C}$ to $37^{\circ} \mathrm{C}$ the high activity as observed as observed in the literature [10] obtained higher cholinesterase activity at $35^{\circ} \mathrm{C}$ in Heterorhabditis bacteriophora. Prochilodus brevis, since fish are pecilothermic animals, in which body temperature adapts to ambient temperature, aquatic environments are cooler, possibly corresponding to an evolutionary adaptation of enzymes with high activity at lower temperatures, may be a biosensor vantage on tropical aquatic system where prevail the temperature below to $30^{\circ} \mathrm{C}$. Thermal stability (Figure $3 \mathrm{~B}$ ) was a method applied to characterize the denaturation of ChE. At the temperature of $28^{\circ} \mathrm{C}$, in which the optimum temperature was evidenced, in the thermal stability there was a fall. Subsequent temperatures where activity was observed decreased for thermal stability analysis showed a behavior of increase of activity. This fact may be related to a type of reversible denaturation, since the perturbation suffered by 
the enzyme benefited the catalytic activity from 31 to $37^{\circ} \mathrm{C}$, after $37^{\circ} \mathrm{C}$ the activity decrease of approximately $80 \%$ up to $46^{\circ} \mathrm{C}$ was observed, suggesting structural instability of the enzyme at the level of an irreversible denaturation.

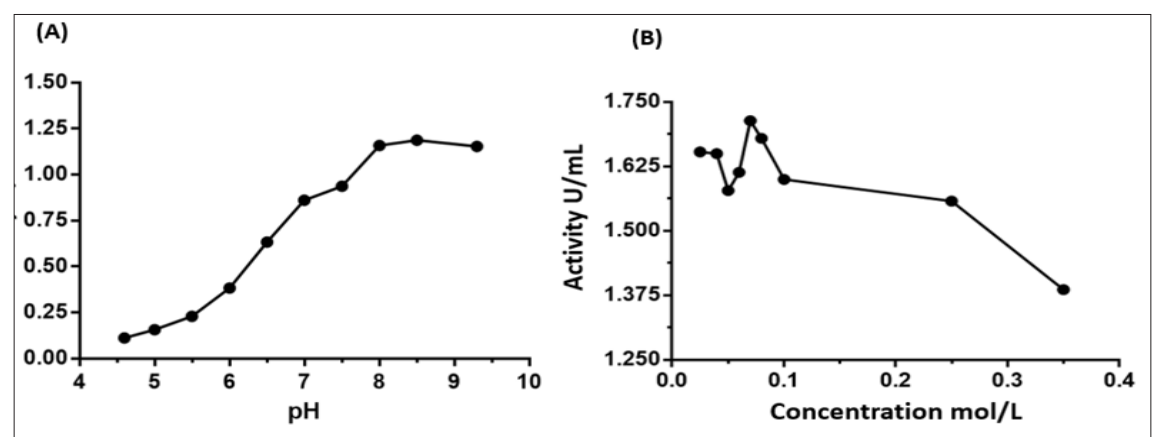

Figure 2: Effect of $\mathrm{pH}(\mathrm{A})$ and ionic strenght (B) on activity of Prochilodus brevis AChE.
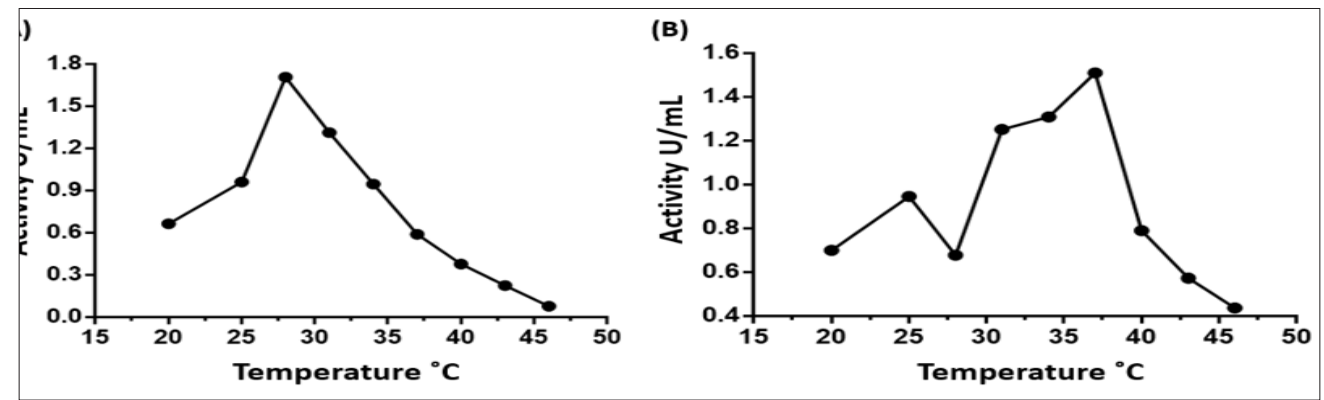

Figure 3: Optimum temperature (A) and thermal stability (B) of Prochilodus brevis AChE.

\section{Electrochemical Studies}

Initially were used CV of ferri/ferrocyanide for polishing the GCE. The MWCNT was adsorbed on the surface of GCE and CVs of ferri/ferrocyanide couple using modified and unmodified GCE for evaluate the barrier created after each modification step. The AChE samples were immobilized by adsorption on MWCNT surface. To study the electrocatalytic activity of AChE towards the oxidation of thiocholine was used the differential pulse voltammetry.
(Figure 4) shows the analytical curve of current vs increase of ACTh concentration of 0.05 to $0.85 \mathrm{mM}$, for each fraction of the purification process. A linear response in the studied concentration range was obtained, whose limits of detection and quantification for each fraction (Table 1). The values were very close, where the ChE1 fraction with detection limit of $73 \mu \mathrm{M}$ and limit of quantification of $240 \mu \mathrm{M}$ was higher. The purification process reflected in the oxidation potential, to favor the reduction of the potential between free cell fraction and ChE1.

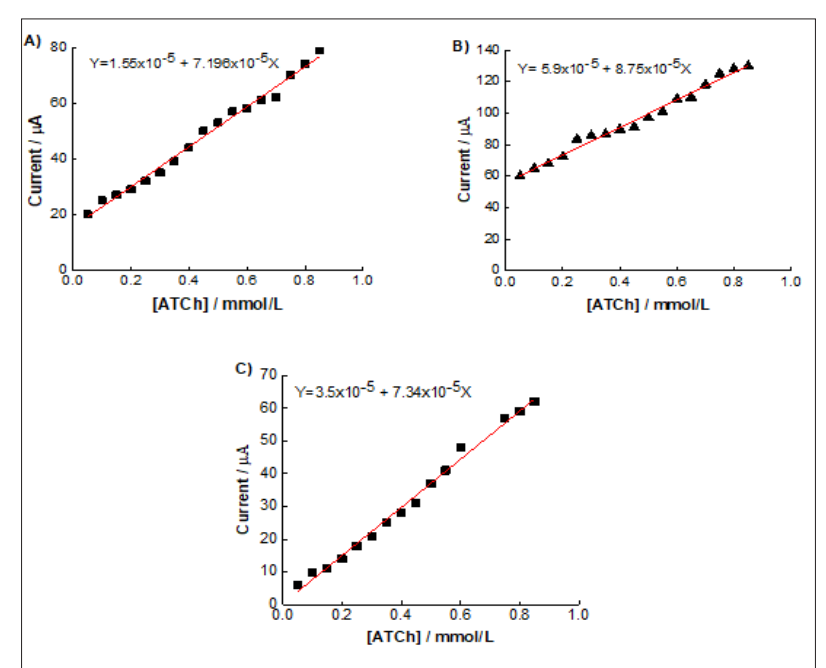

Figure 4: Plot current vs increase of ATCh concentration of 0.05 to $0.85 \mathrm{mM}$, by DPV with modified electrode A) fraction cellfree, B) dialyzed e C) ChE1. 
Table 1: Obtained data from the analytical curves for biosensor GCE/MWCNT/fraction of the brain extract of $P$. brevis.

\begin{tabular}{|c|c|c|c|c|}
\hline Fraction & \multicolumn{1}{c}{ E / V } & \multicolumn{1}{c}{ R } & DL / $\mathbf{m M}$ & $\mathbf{Q L} / \mathbf{m M}$ \\
\hline Cell free & 0.68 & 0.989 & 0.075 & 0.26 \\
\hline Dialyzed & 0.70 & 0.985 & 0.091 & 0.30 \\
\hline ChE1 & 0.64 & 0.991 & 0.073 & 0.24 \\
\hline
\end{tabular}

The spherical shape of MWCNT have good biocompatibility with enzymes $[11,12]$. A special electron transfer between AChE and the electrode surface and adsortive interaction helps to conserve the structure and catalytic properties of AChE, showing to be potentially useful for the construction of electrochemical biosensors. The combination of AChE interaction with MWCNT shows an increase in the surface area of the electrode, which is reflected in the current values obtained for the modified electrode.

\section{Conclusion}

As can be seen, the AChE from curimatã fish brain allowed the construction of the biosensor, both the cell free extract and the dialyzed and partially purified fraction, showed good cholinesterase enzymatic activity in the hydrolysis of acetylthiocholine monitored by the anodic oxidation of the generated thiocholine, with values of limits of detection and quantification close to each other. This work provides a potential sensor detection system that can be used for determination of thiocholine in real samples of environmental importance.

\section{Acknowledgement}

The authors are grateful to Brazilian agencies CNPq, CAPES, FAPEAL for financial support.

\section{References}

1. Ahmed M, Latif N, Ra K, Ahmad A, Jbt, R, et al. (2012) Enzymatic and biochemical characterization of Bungarus sindanus snake venom acetylcholinesterase. 18(2): 236-243.

\section{ISSN: 2574-1241}

DOI: 10.26717/BJSTR.2018.08.001655

Fabiane Caxico de Abreu. Biomed J Sci \& Tech Res

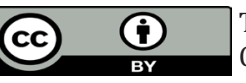

This work is licensed under Creative Commons Attribution 4.0 License

Submission Link: https://biomedres.us/submit-manuscript.php
2. Rotundo RL (2003) Expression and localization of acetylcholinesterase at the neuromuscular junction. Journal of Neurocytology 32(5-8): 743766.

3. Andreescu S, Marty J (2006) Twenty years research in cholinesterase biosensors: From basic research to practical applications. 23(1): 1-15.

4. Massoulié J, Bon S (1982) The molecular forms of cholinesterase and acetylcholinesterase in vertebrates. France Ann Rev NeuroscL pp. 57106.

5. Hicks D, John D, Makova NZ, Henderson Z, Nalivaeva NN, et al. (2011) Membrane targeting, shedding and protein interactions of brain acetylcholinesterase. Journal of Neurochemistry 116(5): 742-746.

6. Sagane Y, Nakagawa T, Yamamoto K, Soichi Michikawa, Suguru Oguri, et al. (2005) Molecular Characterization of Maize Acetylcholinesterase. A Novel Enzyme Family in the Plant Kingdom. Plant Physiology 138(3): 1359-1371.

7. George L Ellman, $\mathrm{K}$ Diane Courtney, Valentino Andres, Robert $\mathrm{M}$ Featherstone (1961) A new and rapid colorimetric determination of acetylcholinesterase activity. Biochemical Pharmacology 7(2): 88-95.

8. Yan xia YANG, Li zhi NIU, Shao nan LI (2013) Purification and studies on characteristics of cholinesterases from Daphnia magna. Journal of Zhejiang University-SCIENCE B (Biomedicine \& Biotechnology) 14(4): 325-335.

9. Mohamed MA, Abdel Gawad AS, Ghazy A EM (2007) Purification and characterization of an acetylcholinesterase from the infective juveniles of Heterorhabditis bacteriophora. Comparative Biochemistry and Physiology, part C 146(3): 314-324.

10. Centeno DA, Solano XH, Castillo JJ (2017) A new peroxidase from leaves of guinea grass (Panicum maximum): A potential biocatalyst to build amperometric biosensors. Bioelectrochemistry 116: 33-38.

11. Cosnier S, Holzinger M, Goff AL (2014) Carbon Nanotubes: A Review on Structure and Their Interaction with Proteins. Front Bioeng Biotechnol 2(45): 1-6.

12. Saifuddin N, Raziah, AZ, Junizah AR (2013) Recent Advances in Carbon Nanotube-Based Enzymatic Fuel Cells. Journal of Chemistry 1-18.

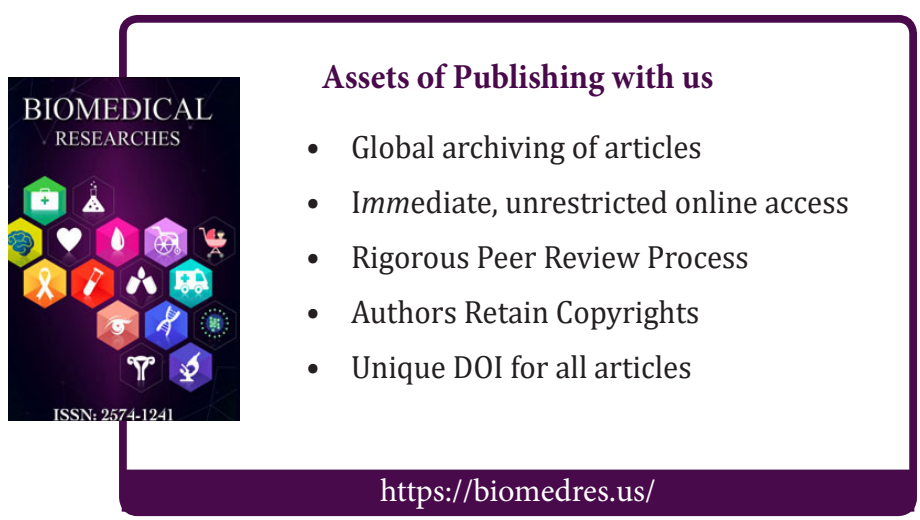

